SPECIAL VOLUME

\title{
Geology and Mineral Potential of Copper-Silver mineralization in Kulu district of Himachal Pradesh, India
}

\author{
Rajinder Kumar ${ }^{1 *}$, Surendra Kumar ${ }^{1}$, Ratikant Sikdar ${ }^{1}$ \\ ${ }^{1}$ Geological Survey of India, Chandigarh, India
}

\begin{abstract}
* Corresponding author : rajindergsi@gmail.com
Tel.: +91-9313502359

Received: Sept 14, 2018; Accepted: Mar 22, 2019.

DOI: 10.25299/jgeet.2019.4.2-2.2127
\end{abstract}

\begin{abstract}
Naraul Formation of the Larji Group in Kulu district of Himachal Pradesh contains the major strata bound Copper mineralization at many places as observed through old working near Naraul, Danala and Kanda in Sainj Valley of Kulu district exposing the Proterozoic Northwestern Himalayan belt. The same structural belt is also known for Silver mineral isation around Manikaran. At Naraul, a regional stratigraphic and mineralogical framework of the Naraul Formation for mineralogical resource assessment was viewed. The old workings within $4-5 \mathrm{~km}$ long and 200-300m wide along the NW- SE trending structural trend cover the main ore potential zones. The ore mineralisation seems to be alike the copper silver deposit of the Revett Formation of Montana and Idaho, USA. The deposit in Naraul needs further more drilling investigation and exploration for actual reserve assessment.
\end{abstract}

Keywords: Kullu, Naraul, Copper deposit, Sainj valley

\section{Introduction}

Generally, the strata-bound Copper-Silver deposit contain 23 percent of all the copper-silver resource and form the second important global source of these metals after the porphyry copper deposits. The Naraul Formation of Larji Group in the NW-SE Himalayan and the Kulu Group of rocks at Uchich, both trending along NW-SE as a belt, are known for Copper mineralisation around Naraul in Sainj Valley and Silver mineralisation at Uchich in Parvat Valley of Kulu district in Himachal Pradesh. The Copper-Silver mineralisation in NW-SE trending quartzite at Naraul contains the most significant resource known only from the past old workings only. It may become one among the significant strata-bound $\mathrm{Cu}-\mathrm{Ag}$ deposit. The Naraul Formation constituting different types of rocks like calc-quartzite, siltite, impure carbonate (limestone) and quartzite out of which the fine to medium grained calc quartzite/siltite do contains mainly the large stratabound base metal mineralization. The present study reveals that Naraul-Danala-Kanda may contain significant Copper-Silver mineralisation in siltite/quartzite having a resemblance with the Revett-type mineralisation of Montana, USA.

\section{Origin of the Coper-Silver mineralisation}

The Naraul Formation of the Larji Group forms a part of the Mesoproterozoic age which consists of quartzite, siltite, and argillite (very fine grained to medium grained), quartz-rich metamorphosed sedimentary deposits. The thick vertical to steep dipping beds of massive white calc-quartzite of the Naraul Formation showing the malachite and azurite basically form the main significant hoist for Copper and other associated minerals namely silver and nickel. Metals were deposited where oxidized metals bearing brine upwelled along the faults/ thrust plains as well; and migrated laterally altering the preexisting pyrite-hematite interfaces in the sediments. The ore mineralization occurs as syngenetic dissemination type in the form of specks, grains and strings of chalcopyrite, covellite, siegenite, and pyrite.

The mineralization is characterized by mineralised and alternation zones which provide source and guide for minerals. Regional changes in the mineral zones, thickness and grain size variation in hoist rocks and the geological structure provide evidence of fluid movements in the sediments and during formation of $\mathrm{Cu}-\mathrm{Ag}$ deposits and provide a framework to evaluate the potential for undiscovered deposits.

\section{Ore-Mineralization}

The ore minerals identified at Naraul old workings include chalcopyrite, pyrrhotite, chalcocite and pyrite. Potential mineralisation zones occur in two major valleys in the study area i.e. Garsha valley and Sainj valley. A 
number of old workings are present in the Garsha valley on either side of the hill range running in the NW-SE direction. The mineralisation occur in two parallel discontinuous zones which preserve \& mark old working and define the mineralised parts. The old workings present in the area follow strike parallel extensions having dip wise deep extensions for manual extraction and crude mining of ore loads since earlier times. The important old workings include Gobha, Naraul, Lalgi, Kalpana, Danala and Dudhru. Most of these are situated on steep escarpment faces and have difficult accessibility. Structurally the mineralization is confined to the strata bound hoists and show remobilization and relocalisation along the pervasive structural elements.

Generally, disseminations, streaks and thin stringers of chalcopyrite, pyrite and specularite are reported from rocks of the Naraul Formation. The hosts rocks towards east on the hanging wall side consists of conglomeratic quartzite and phyllite, whereas, the hoist rocks on footwall side comprises grey phyllite and quartzite. At places, the mineralization confined to their hosts is of very sparse and sporadic nature.

Structurally controlled mineralization is usually localized and remobilised mineralisation is associated with the shears and fractures. Few quartz veins do invariably carry mineralization. A prominent longitude shear zone al ong $\mathrm{N} 15^{\circ} \mathrm{W}-\mathrm{S} 15^{\circ} \mathrm{E}$ in almost all the old workings indicates a conduit for the base metal mineralization. The old workings are confined to the Calc-quartzite hoisted in Naraul Formation. The copper mineralisation in the Gadsha Valley extends from Gobha in the north through Naraul, Lalgi, Kalpana, and Danala to Dudhru in the south. The sporadic occurrence of the old workings at the above localities bears testimony to the extensive mining activity in the recent pasts. Besides, sporadic specks dissemination and stringers of chalcopyrite and pyrite are present. Malachite and azurite stains and encrustations on rock surfaces have specks, sporadic thin stringers and fine disseminations of chalcopyrite, pyrite and rarely covellite.

The oxidized faces of the old workings at the Lalgi show 'Cobalt bloom' wherein the mineralization occur in association of massive quartzite, conglomeratic quartzite and calcareous quartzite belonging to Naraul Formation. A persistent linear shear/fracture along NNW-SSE with small oblique shears appear to act as conduit for the mineralizing solutions. Old Working at Gobha in massive quartzite show sparse, fine disseminations of chalcopyrite and pyrite and stains of malachite and azurite and forms the northern most old-working at 2240 msl towards northwest of Naraul. The mineralization occurs along N-S trend over a length of about 50m having about six-meter width of the exposed old working.

Old Working at Naraul showing the vertical facing escarpment supports 13 old small old workings along a NNW-SSE extending linear trend for over a distance of about 350 meter. The ore minerals occur within calcquartzite trending along NNW-SSE strike having dips of $45^{\circ}$ to $65^{\circ}$ towards east. The width of mineralization zone in Naraul old workings varies from $5 \mathrm{~m}$ to $15 \mathrm{~m}$ among the forest cover. At places, the inner walls of old workings reveal cobalt $(\mathrm{Co})$ and nickel $(\mathrm{Ni})$ ore minerals besides copper ores. On surface, the encrustation of malachite, azurite and Chalcanthite are very common. The hoist rocks at old workings around Naraul show fine disseminations and thin stringers of chal copyrite and pyrite. The samples from heaps of slag in the proximity of the nearby villages of Naraul and Mahun indicate the past smelting. The slag samples from Mahun indicated 1.11 to $2.25 \%$ copper and samples from Naraul show $1.76 \%$ copper and $0.17 \%$ cobalt. The average grade of Cu is $1.11 \%$ with an average thickens of $3.86 \mathrm{~m}$ over a strike length of $180 \mathrm{~m}$. Moreover, minerals like cobalt and nickel with average values of 438 ppm and 243 ppm are also associated with copper (Sharma, 1997). These old-workings structurally occur in the vertical escarpment face within the massive and conglomeratic quartzite. The shapes of these old workings are usually lensoidal. Very sparse and fine disseminations of chalcopyrite with some pyrite were observed in these old workings.

Similarly, the $30 \mathrm{~m}$ long and ten-meter-wide Old Working at Lalgi, two kilometre southwest of Naraul old workings, on the western face of the Jamir ridge also show similar features. Pockets cobalt bloom and chalcopyrite were noticed observed in mine. The mineralization appears to occurs within the calcareous quartzite over a strike length of about $27 \mathrm{~m}$. along NE shear zone. The base metal mineralization is richer in the portions traversed by the vein quartz within a width of $2.5 \mathrm{~m}$ showing chalcopyrite and malachite stains. Similarly, the old working at Danala and Dudhru, indicate copper ore mineralization at $2400 \mathrm{~m}$ elevation in $90 \mathrm{~m}$ $x 45 \mathrm{~m}$ dimension within white siltite showing high density of joints.

The south-east extension of Danala-Dudhru old workings are traceable around Naraul, Phabiari, Kanda and Spangani in the Sainj area. During regional deformation \& metamorphism, the ore minerals have remobilised and are structurally controlled.

\section{Mineral Potential}

The present study reveals nature of distribution of ore minerals, grain size and primary distribution and alteration of mineralogy and the stratigraphic of the Naraul Formation. The field observations reveal that the strata bound copper silver deposit in Naraul Formation, need more drill core sections to understand potential and the flow paths of the brines in the sedimentary hoists rocks where mineral recourse development must be weighed against other land-uses. This study will be a useful guide for actual mineral resource. Resource assessment of the Cu-Ni Naraul deposit needs further promising explorations in the surrounding area in NW-SE structural extensions which constitutes the strata bound minor silver prospects at Uchich near Varshaini at Manikaran in Parvati Valley of Kulu district in Himachal Pradesh. The silver mineralisation at Uchich is hoisted along tectogenic thrust in carb-phyllite of Manikaran Formation of Rampur Group. Besides, the base metal 
mineralization at Naraul is another such considerable strata bound deposit at Naraul in Kulu district of Himachal Pradesh.

The copper $(\mathrm{Cu})$ content of ores varies from $0.007 \%$ to $0.95 \%$ while nickel and cobalt occur in traces. The old workings having slags from Mahun indicated 1.11 to $2.25 \% \mathrm{Cu}$ (Copper) and from Naraul it is about $1.76 \% \mathrm{Cu}$ and $0.17 \%$ Co (Cobalt) (Sharma, 1968;Sharma, 1992). The average grade of Cu is $1.11 \%$ with an average thickens of $3.86 \mathrm{~m}$ over a strike length of $180 \mathrm{~m}$. Moreover, minerals like cobalt and nickel with average values of $438 \mathrm{ppm}$ and 243 ppm are also associated with copper (Sharma, 1997). In calcareous and conglomeratic quartzite around Gobha and Khaniari the base metals show higher values of $\mathrm{Cu}, \mathrm{Pb}, \mathrm{Zn}, \mathrm{Co}, \mathrm{Ag}, \mathrm{Cd}$, and $\mathrm{Mn}$ in stream sediments (Kumar, 2005).

The pyritohedron crystals of pyrite present in the sheared white quartzite indicate Group-II type of metamorphogenic pyrite deposit hoisted in the deltaic plain and lacustrine meta-sediments (Murowchicka and Barnses,1987).

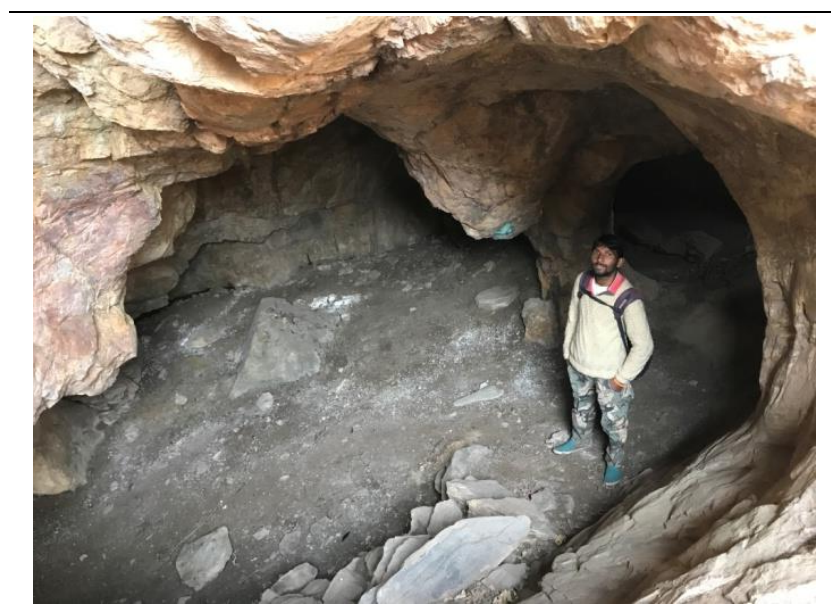

Fig.1 Open cast old working at Lalgi mine in Calcareousquartzite, Sainj Valley, Kulu.

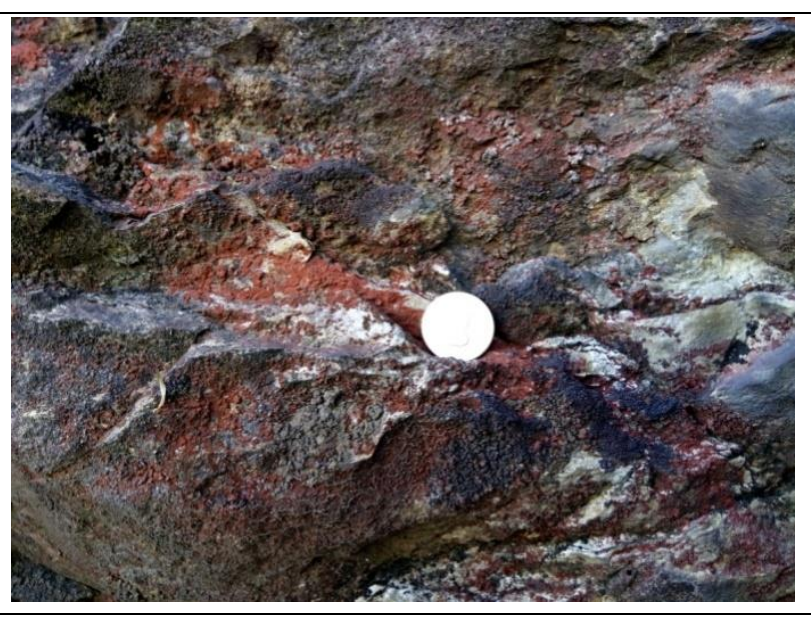

Fig.2: Face of an old working showing oxide ore minerals in sheared quartzite at Naraul, Sainj Valley, Kulu.

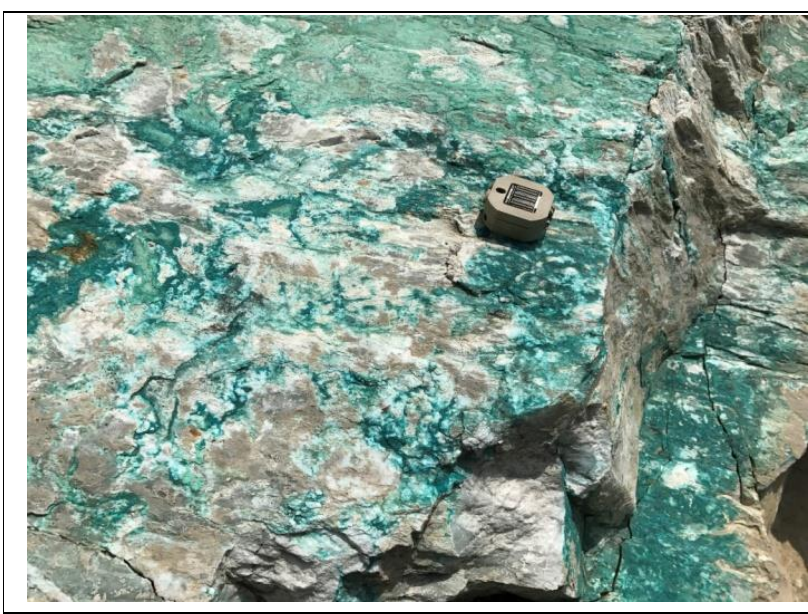

Fig.3 Malachite and azurite stains in calcareous quartzite of Naraul Formation, Kanda, Sainj Valley, Kulu.

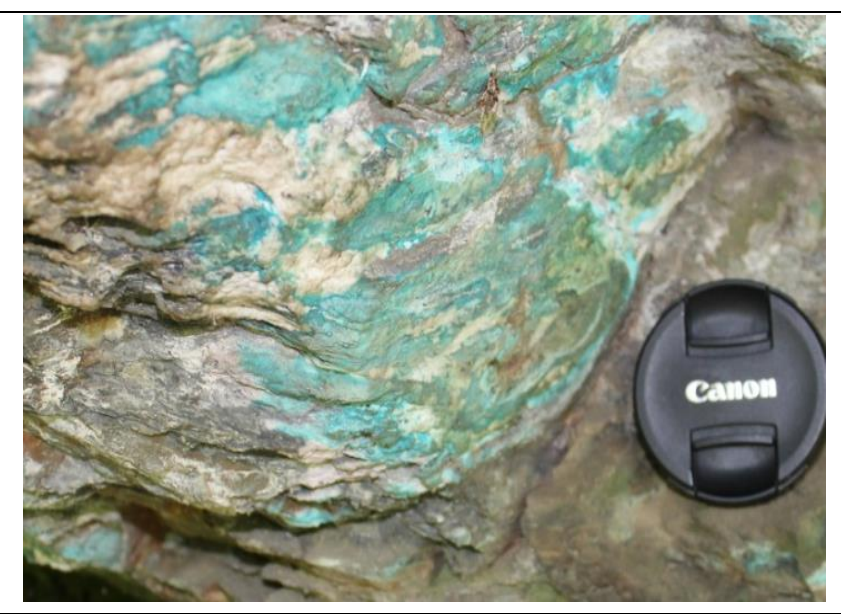

Fig.4.:Malachite in grey calcareous quartzite, at Naraul, Sainj Valley, Kulu.

\section{Discussion}

The ore mineralization hoisted in the Proterozoic Northwestern Himalayan belt in the Naraul Formation of Larji Group in Kulu district of Himachal Pradesh is known for major strata bound Copper-Silver mineralization as notices through old working in Naraul area in Gadsha and Sainj Valley of Kulu district. The ore mineralisation seems to be alike the copper silver deposit of the Revett Formation of Montana and Idaho, USA. The old workings in Naraul area are confined within 4-5 km long and 200-300m wide along the NW- SE trending structural trend covering the main ore potential zones in siltites. The area shows low to medium grade of metamorphogenic characters of ore minerals. The pyritohedron crystals of pyrite found in the sheared white quartzite indicates 
Group-II type of metamorphogenic pyrite deposit which indicates deltaic plain and lacustrine palaeoenvironments of the metamorphosed host rocks.

\section{References}

Kumar, R., 2005. Report on Geochemical mapping in parts of Gadsha-Naraul area, in Kulu district of Himachal Pradesh, Geological Survey of India, Chandigarh.

Murowchick, J.B., Barnes, H.L., 1987. Effects of temperature and degree of super-saturation of pyrite morphology, American Mineralogist, 72, 1241-1250.

Sharma, R. K.,1968. Report on Mineral Investigation of base metals at Naraul, Kullu district, Himachal Pradesh, Geological Survey of India, Chandigarh

Sharma, R. K.,1992. Report on Mineral Investigation of base metals at Naraul, Kullu district, Himachal Pradesh, Geological Survey of India, Chandigarh

Sharma, R.K.,1997. Report on Mineral Investigation of base metals at Naraul, Kullu district, Himachal Pradesh, Geological Survey of India, Chandigarh. 